\title{
Quality of Life of Disabled Children Study in Special and Inclusive School
}

\author{
Ginan Nugroho* \\ Post Graduate School, Sport Education \\ Universitas Pendidikan Indonesia \\ Bandung, Indonesia \\ *ginannugroho@gmail.com
}

\author{
Yudy Hendrayana, Eka Nugraha \\ Faculty of Sport and Health Education \\ Universitas Pendidikan Indonesia \\ Bandung, Indonesia
}

\begin{abstract}
This research was aimed at describing the quality of life different ability children going to special and inclusive school in Medan City, North Sumatra reviewed by the Domain Quality of Life from each school; physical health, psychology, social and environment, by using cross sectional survey. There were 30 students taken as the research sample who go to special schools and inclusive schools. The data collection technique used in this research was WHOQOL-BREF. The result of the research showed that there was significance of quality of life between children going to special schools and children going to inclusive schools. It was found that children's quality of life going to special schools was higher than children going to inclusive schools.
\end{abstract}

Keywords-quality of life; different ability children; special schools; and inclusive schools

\section{INTRODUCTION}

Children are the grace from the Almighty God for all people as they dream and expect it. Having physically and spiritually normal children is a dream for every family. However, sometimes expectation is not like reality. Some families are given disabled children as they are usually called special-need children [1]. Different ability children are defined widely children who have different ability from others, some of them are stunting in learning process and each child viewed has special needs either permanently or temporarily [2]. The percentage of people with disability in Indonesia is mostly in Bengkulu Province; $3.96 \%$ and the least is in Papua; $1.05 \%$, and based on the Riskesdas in 2013, the largest number of people with disabilities is in Central Sulawesi; $23.8 \%$ and the lowest number is in West Papua; $4.6 \%$ [3]. Based on the research conducted by Edwards, Patrict and Topolski, there were 220 adolescents with different abilities in America showing that adolescents with different abilities has worse quality of life than normal adolescents [4]

The result of the research done by Sun et al showed that children with disabilities sometimes get bad education service. Moreover, most adult people with disabilities do not get job as the normal people get. Those are the real examples of what people with disabilities suffer [5]. In the UK in 1980-1990 special school students were estimated to decline from nine million to around two million due to their returning to regular or public schools, while in the United States, it was estimated that only about $0.5 \%$ of children with special needs attended special schools, others are in regular schools or public schools and apparently the population of students in special schools is less than 3\% [6-8]. Inclusion schools mean schools providing a decent, programmed, challenging education program, but suitable with the abilities and needs of each student, and have a level of equality of various types of tasks and responsibilities to train, mentally, socially and spiritually and is a placement of children with special needs at a good level mild, moderate and severe [7,9-11]. As a system of education service, it is expected that children with special needs can be served in nearby schools, so that schools become adequate learning resources and get support from various parties [12,13]. Carlberg \& Kavale conducted a study of 50 researches on inclusion, and the results showed that inclusive education had a positive impact on both academic and social development of children with special needs [4]. However, on the other hand, there are still shortcomings in terms of teaching staff and this can be seen from several schools that still do not have Guidance and Counseling room, the unavailability of visual aids for children with special needs and the limitations of Special Guidance Teachers in public schools organizing inclusion programs.

Research conducted by Diah and Resnia about family social support, family and environment that can help to improve the life quality of children with special needs so that they can do something useful for their lives and society [14] Quality of Life can be seen as a multidimensional concept because it involves all areas of life including health, hope, work, family, environment, and other life situations [15]. There are several factors affecting a person's quality of life conceptually, such as gender factors, educational factors, employment factors, income factors, social environmental factors, health factors, age factors and marital status factors [16]. Adolescents with special needs in America showed that there were 220 adolescents having lower quality of life than adolescents with normal life in general. They generally have lack of attention from parents, family, environment, and low quality of health services. Those factors can cause their life quality lower $[3,17]$. According to Salamanca, there are several factors that can affect Quality of Life children with special needs such as socio-demography, stress and coping ability, and social support that can increase their quality of life [18] 
Inclusive education is the current development from the education model for children with disabilities, so that schools can be defined as model of life variety like life reality $[14,19,20]$. The efforts to achieve life quality for qualified children can be viewed from various aspects, one of namely physical health, psychology, social relations, and environment, as well as individuals in its field, navigating life in the context of culture and the value of the system in which a person lives, and in relation to achieving a goal, hope, standard, and interest [21,22].

\section{METHOD}

The method used was a descriptive or Trans Versal Cross sectional survey study or Prevalence study where the research is only carried out at one time or one period and observation of the study object is only done once [23]. The participants in this research were all students with special needs who attended Special School for Disabled Children Education Foundation in Medan consisted of 20 students in the middle school education unit and all children with special needs attending inclusive schools of Chandra Kumala School Education consisted of 10 students, so this study used total sampling technique [24].

\section{A. Data Analysis}

The Data analysis done by using SPSS 23.0 software, then to find out the differences of the two variables, the researcher used a different test using the t-test.

Research finding in this study, the normality test used was the Kolmogorov Smirnov Normality test. Data were said to be normally distributed if the value is higher than 0.05 . The results of the normality test can be seen in the following table.

TABLE I. ONE-SAMPLE KOLMOGOROV-SMIRNOV TEST

\begin{tabular}{|c|l|l|l|}
\hline & \multicolumn{2}{|c|}{ Special schools } & \multicolumn{1}{c|}{ Inclusive Schools } \\
\hline $\boldsymbol{N}$ & \multicolumn{2}{|c|}{$\mathbf{2 0}$} & \multicolumn{1}{c|}{} \\
\hline \multirow{2}{*}{$\begin{array}{c}\text { Normal } \\
\text { Parameters }\end{array}$} & Mean & 112.30 & 91.80 \\
\cline { 2 - 4 } & Std. Deviation & 8.157 & 10.315 \\
\hline \multirow{2}{*}{$\begin{array}{c}\text { Extremt } \\
\text { Differences }\end{array}$} & Absolute & .139 & .256 \\
\cline { 2 - 4 } & Positive & .117 & .178 \\
\cline { 2 - 4 } & Negative & -.139 & -.256 \\
\hline \multicolumn{2}{|c|}{ Kolmogorov-Smirnov $\boldsymbol{Z}$} & .622 & .810 \\
\hline \multicolumn{2}{|c|}{ Asymp. Sig. (2-tailed) } & .835 & .527 \\
\hline
\end{tabular}

Based on the above normality test, it was known that all quality of life data in this study obtained a significance value namely $>0.05$. Therefore, it can be concluded that all data in this study are normally distributed. Data can be said to be homogeneous if the number of significance is greater than 0.05 . Homogeneity test results can be seen in the following table.

TABLE II. GROUP STATISTICS

\begin{tabular}{|l|l|l|l|l|c|}
\hline & Group & N & Mean & $\begin{array}{c}\text { Std. } \\
\text { Deviation }\end{array}$ & $\begin{array}{c}\text { Std. } \\
\text { Error } \\
\text { Mean }\end{array}$ \\
\hline $\begin{array}{l}\text { Quality } \\
\text { of Life }\end{array}$ & $\begin{array}{c}\text { Special } \\
\text { School }\end{array}$ & 20 & 112.30 & 8.157 & 1.824 \\
\cline { 2 - 6 } & Inclusive & 10 & 91.80 & 10.315 & 3.262 \\
\hline
\end{tabular}

TABLE III. INDEPENDENT SAMPLES TEST

\begin{tabular}{|c|c|c|c|c|c|c|c|c|c|c|}
\hline & \multicolumn{2}{|c|}{$\begin{array}{c}\text { Levene's Test for } \\
\text { Equality of Variances }\end{array}$} & \multicolumn{7}{|c|}{ t-test for Equality of Means } \\
\hline & & \multirow[t]{2}{*}{$F$} & \multirow[t]{2}{*}{ Sig. } & \multirow[t]{2}{*}{$t$} & \multirow[t]{2}{*}{$D f$} & \multirow[t]{2}{*}{$\begin{array}{l}\text { Sig. }(2- \\
\text { tailed })\end{array}$} & \multirow[t]{2}{*}{$\begin{array}{c}\text { Mean } \\
\text { Difference }\end{array}$} & \multirow[t]{2}{*}{$\begin{array}{l}\text { Std. Error } \\
\text { Difference }\end{array}$} & \multicolumn{2}{|c|}{$\begin{array}{l}\text { 95\% Confidence } \\
\text { Interval of the } \\
\text { Difference }\end{array}$} \\
\hline & & & & & & & & & Lower & Upper \\
\hline \multirow{2}{*}{$\begin{array}{l}\text { Quality } \\
\text { of life }\end{array}$} & Equal variances assumed & .044 & .836 & 5.942 & 28 & .000 & 20.500 & 3.450 & 13.433 & 27.567 \\
\hline & Equal variances not assumed & & & 5.485 & 14.822 & .000 & 20.500 & 3.737 & 12.526 & 28.474 \\
\hline
\end{tabular}

Based on the output, it was known that the average Quality of Life the total school students was 112.30 and the average Quality of Life in the school students. Inclusion 91.80, so that the average Quality of Life students with special needs in special school students is higher than the students of Inclusion schools.

Based on the independent sample t-test above, it was gained the significance value $0.000<0.05$. It means that there was life quality difference between children attending special schools and children attending inclusive schools. It can be seen from the mean difference Colum showing the significance 20.500 or in the table 4.3 the life quality of children with special needs attending special schools are higher than children with special needs attending inclusive schools.

\section{CONCLUSION}

In this study the Quality of Life children with special needs attending special schools and inclusive schools have differences in terms of the Quality of Life domain of children with special needs where children with special needs attending special schools higher than the Quality of Life of children with special needs attending inclusive schools.

\section{ACKNOWLEDGMENT}

The author would like to thank Mr. Yudy Hendrayana and Mr. Eka Nugraha as Counselors in this study and Lembaga Pengelola Dana Pendidikan (LPDP) for providing financial assistance to complete this entire research.

\section{REFERENCES}

[1] B.G. Clark, J.E. Magill-Evans and C.J. Koning, "Youth with autism spectrum disorders: Self-and proxy-reported quality of life and adaptive functioning," Focus on Autism and Other Developmental Disabilities, vol. 30, no. 1, pp. 57-64, 2015.

[2] UNESCO, Tulkit LIRP - Merangkul Perbedaan: Perangkat untuk Mengembangkan Lingkungan Inklusif Ramah terhadap Pembelajaran, 
Buku khusus 3 : Mengajar Anak-anak dengan Disabilitas dalam Seting Inklusif. 2009.

[3] N. Diah and N. Resnia, The relationship between social support and quality of life in patients with heart failure, vol. 16, no. 4, pp. 40-8, 2017

[4] C.D. Barutcu and H. Mert, "The relationship between social support and quality of life in patients with heart failure," J Pak Med Assoc, vol. 63, no. 4, pp. 463-7, 2013

[5] W. Sun, M. Wu, P. Qu, C. Lu, and L. Wang, "Quality of Life of People Living with HIV/AIDS under the New Epidemic Characteristics in China and the Associated Factors," PLoS One, vol. 8, no. 5, 2013.

[6] J. Kraus, "The Effects of Committal to a Special School for Truants," pp. 130-8, 1977.

[7] K.S. Quick and M.S. Feldman, "Distinguishing participation and inclusion,” J Plan Educ Res. vol. 31, no. 3, pp. 272-90, 2011.

[8] Warnock, "Special Educational Needs: Report of the committee of enquiry into the education of handicapped children and young people," In: Her Majesty's Stationery Office, 9-12, 1978.

[9] Stainback. Together in Inclusive. Counc Except Child. 1996;

[10] R. Vanderstraeten, "Inclusion ideals and inclusion problems: Parsons and Luhmann on religion and secularization," Acta Sociol (United Kingdom), vol. 58, no. 2, pp. 173-85, 2015.

[11] D.S. Bassett, L. Jackson, K.A. Ferrell, J. Luckner, P.J. Hagerty and T. Bunsen, "Multiple Perspectives on Inclusive Education: Reflections of a University Faculty," Teach Educ Spec Educ, vol. 19, no. 4, pp. 355-86, 1996.

[12] Barton, "Teachers and School Psychologists Perception of School Psychologists,” Percept Mot Skills, vol. 60, no. 1, pp. 1003-9, 1985.
[13] M. Sapon-shevin, "Working Towards Merger Together: Seeing Beyond," Teach Educ Spec Educ., vol. 11, no. 3, pp. 103-10, 1988.

[14] J.D. Tanner, V. Linscott, F. County and G.A. Schools, Guru Sekolah Menengah, 1996

[15] M.A. Roth and S.E. Miller, "Transdisciplinary Teaming in Special and Education Preach," Teach Educ Spec Educ, vol. 14, no. 4, pp. 243-7, 2015

[16] P. Moons, W. Budts and S. De Geest, "Critique on the conceptualisation of quality of life: A review and evaluation of different conceptual approaches,” Int J Nurs Stud., vol. 43, no. 7, pp. 891-901, 2006.

[17] N. Novitasari, "The relationship between social support and quality of life in patients with heart failure," vol. 63, no. 4, pp. 463-7, 2013.

[18] S. Crawford, "An examination of current adapted physical activity provision in primary and special schools in Ireland," Eur Phys Educ Rev., vol. 17, no. 1, pp. 91-109, 2011.

[19] M. Asrorul, International Seminar of Special Education: Education for All (EFA) Implementation toward Children with Special Needs in The Era of ASEAN Economic Community (AEC) 2015, 2015.

[20] P. Clough and C. Nutbrown, "Special educational needs," vol. 2, no. 2, pp. 191-211, 2004

[21] WHO, "Introduction, Administration, Scoring And Generic Version Of The Assessment Field Trial Version December 1996 Programme On Mental Health World Health Organization," 1996.

[22] D.R. Urbach, "Measuring quality of life after surgery," Surg Innov., vol 12, no. 2, pp. 161-5, 2005.

[23] E.R. Prevost, "The problem of quality of life in ministry," Rev Expo, vol. 113 , no. 3 , pp. 315-32, 2016.

[24] I. Etikan, "Comparison of Convenience Sampling and Purposive Sampling,” Am J Theor Appl Stat, vol. 5, no. 1, pp. 1, 2016. 